\title{
COMO PRODUZIR CONHECIMENTO NOS ENCONTROS \\ ENTRE MULHERES? REFLEXÕES SOBRE EXPERIÊNCIAS \\ TEÓRICO-METODOLÓGICAS COM E DESDE AS MARGENS DA CIDADE
}

\author{
Vanessa Alves Cordeiro* \\ Aleida Fontoura Batistoti* \\ Zara Pereira Rodrigues ** \\ Marina Silveira Muniz Ferreira* \\ Atailon da Silva Matos Silva* \\ *Universidade Federal da Bahia, Programa de Pós-Graduação em Arquitetura e Urbanismo, Salvador, BA, Brasil \\ *Urbanista e arquiteta, profissional autônoma, Salvador, BA, Brasil
}

\begin{abstract}
Resumo
Este artigo é resultado de inquietações elaboradas coletivamente no grupo de estudos Margear (UFBA). Ele objetiva evidenciar e refletir sobremodos depensar, pesquisar e narrar cidades de uma perspectiva interseccional. Tomando partido de fragmentos produzidos em nossas pesquisas, destacamos experimentações teórico-metodológicas que praticamos, assim como estratégias para pensar e narrar por meio de linguagens que não apenas a escrita. Nos processos de pesquisa, as principais reflexões que nos movimentaram foram: produção de conhecimento desde e com as margens; valorização da memória; trajetórias urbanas de mulheres negras; imbricações de modos de vida no fazer-cidade cotidiano. As trocas inter e transdisciplinares têm nos fornecido considerações fecundas, mas reforçamos que o campo dos estudos urbanos ainda carece da construção de um arcabouço teórico que o aproxime de alargamentos epistêmicos necessários à sua atualização.

Palavras-chave

Salvador, Bahia; Fazer-cidade; Margens; Mulheres negras; Pesquisa implicada; Experimentações metodológicas.
\end{abstract}




\title{
HOW TO PRODUCE KNOWLEDGE IN ENCOUNTERS BETWEEN WOMEN? REFLECTIONS ON THEORETICAL- METHODOLOGICAL EXPERIENCES WITH AND FROM THE CITY'S MARGINS
}

\author{
Vanessa Alves Cordeiro* \\ Aleida Fontoura Batistoti* \\ Zara Pereira Rodrigues ** \\ Marina Silveira Muniz Ferreira* \\ Atailon da Silva Matos Silva* \\ *Universidade Federal da Bahia, Programa de Pós-Graduação em Arquitetura e Urbanismo, Salvador, BA, Brazil \\ **Urban planner and architect, self-employed professional, Salvador, BA, Brazil
}

\begin{abstract}
This paper arises from concerns collectively elaborated in the study group Margear (UFBA) and aims to highlight and reflect on ways of thinking, researching and narrating cities from an intersectional perspective. Taking advantage of fragments produced from our researches, we highlight some theoretical-methodological experiments practiced, as well as the narration strategies through languages other than writing. In these research processes, the main reflections that moved us were: the production of knowledge from and with the margins, the valorization of memory, the urban trajectories of black women, and the imbrications of ways of life in everyday doing-city. We believe that inter and transdisciplinary exchanges have provided us with fruitful considerations, but we emphasize that the field of urban studies still lacks the construction of a theoretical framework that brings it closer to the epistemic expansions necessary for its updating.

Keywords

Salvador, Bahia; Doing-city; Margins; Black women; Involved research; Methodological experiments.
\end{abstract}




\title{
COMO PRODUZIR CONHECIMENTO NOS ENCONTROS ENTRE MULHERES? REFLEXÕES SOBRE EXPERIÊNCIAS TEÓRICO-METODOLÓGICAS COM E DESDE AS MARGENS DA CIDADE
}

\author{
Vanessa Alves Cordeiro \\ Aleida Fontoura Batistoti \\ Zara Pereira Rodrigues \\ Marina Silveira Muniz Ferreira \\ Atailon da Silva Matos Silva
}

\section{Aberturas}

Com este artigo, ensaiamos algumas reflexões sobre modos de pensar, pesquisar e narrar as cidades de uma perspectiva interseccional, evidenciando aquilo que temos praticado no grupo de estudos Margear' (Figura 1). As questões aqui trabalhadas foram instigadas por inquietações de um movimento coletivo de trocas e encontros vivenciado não apenas entre as autoras², mas também, e principalmente, no interior do próprio grupo de estudos, que tem se fortalecido como espaço de compartilhamento e adensamento de reflexões, além de ser lugar de formação e/ ou atuação de estudantes, pesquisadoras e professoras.

Grande parte dessas inquietações tem nos acompanhado desde a graduação, atravessando-nos como mulheres. Elas se tornaram, ao longo do tempo, inescapáveis às nossas práticas de pesquisa. De fato, as jornadas individuais convergiram para propósitos caros a todas nós, determinando uma busca por perspectivas

\footnotetext{
1. O grupo de estudos Margear - em processo de reconfiguração, já que até recentemente apresentava-se como grupo de estudos Urbanidades Liminares - é sediado na Faculdade de Arquitetura da Universidade Federal da Bahia (UFBA), sendo vinculado ao Programa de Pós-graduação em Arquitetura e Urbanismo. É coordenado pela professora Thaís Troncon Rosa, orientadora das pesquisas que embasam este texto. Agradecemos a essa professora imensamente, não só por ter alimentado nossas reflexões, colaborando com suas leituras cuidadosas e indicações bibliográficas, como também pela manutenção do grupo como espaço de afeto e acolhimento, no qual podemos compartilhar projetos políticos de vida, considerações teóricas e experiências de pesquisa.

2. Utilizamos a flexão de gênero no feminino quando em referência a um coletivo, de modo a não reproduzir a herança patriarcal, na qual o masculino opera como concordância em gênero universal. Sobre desconstrução linguística, ver KILOMBA, G. "Carta da autora à edição brasileira”. In: KILOMBA, G. Memórias da Plantação: episódios de racismo cotidiano. Rio de janeiro: Cobogó, 2019.
} 
críticas, engajamentos e implicações políticas em relação às dimensões sociais e humanas constituintes da cidade. Ao lado dessas concepções, encontra-se, ainda, nossa composição diversa como grupo de autoras que se juntam neste texto: um homem negro e quatro mulheres negras e brancas, LGBTQIAP+, nordestinas, originárias e/ou engajadas politicamente com os territórios onde as pesquisas se constroem.

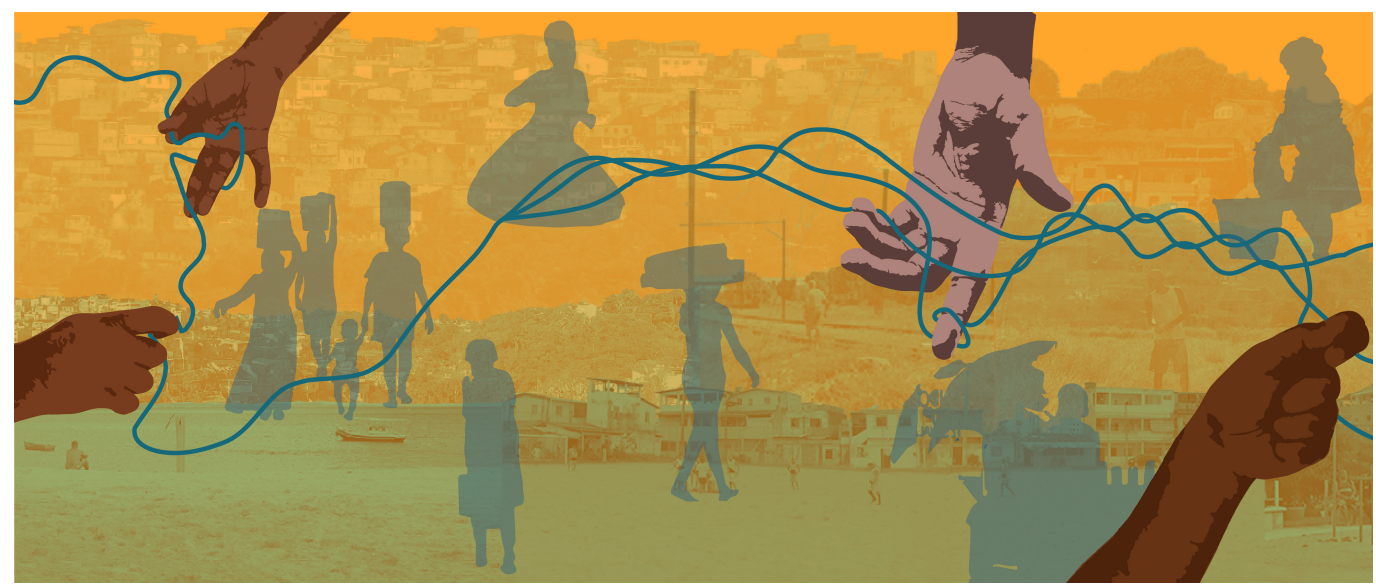

Figura 1. Cidades-margens

Fonte: Acervo do grupo de estudos Margear, 2020.

Temos investigado formas de articular universidade e cidade, pesquisa científica e territórios populares ${ }^{3}$ e negros, construção de conhecimento sobre, com e das margens da cidade (ROSA, 2018) ${ }^{4}$. Consideramos como territórios populares e negros aqueles territórios que são apropriados por pessoas negras das camadas populares, embora não exclusivamente (RATTS, 2012), e, também, aqueles que qualificaram historicamente a experiência coletiva de pessoas negras em diáspora, tendo em vista que eles são uma "força propulsora” (SODRÉ, 2002, p. 13) necessária à constituição e continuidade de suas identidades, bem como do reconhecimento delas entre si. Além disso, cabe destacar que a ideia de construir conhecimento com as margens dialoga com as reflexões de Ribeiro (2012), como forma de apontar a construção mútua de saberes por meio das interlocuções e vivências compartilhadas, e se expande para o desde, buscando evidenciar as epistemologias produzidas a partir das margens como lugar de possibilidades radicais (HOOKS, 1990).

3. Apesar de seu uso controverso, homogeneizando identidades e apagando questões estruturantes da sociedade brasileira - questão a ser tensionada ao longo do presente texto -, utilizamos o termo "popular” atrelado à dimensão étnico-racial, devido ao histórico imbricamento entre raça e classe.

4. Para refletir sobre as "situações periféricas” urbanas no país, evocamos a noção de margens, recusando-nos a pensá-las pela ótica da ausência ou exclusão. Assumimos sua intrínseca perspectiva relacional, de um viés crítico e político. Para aprofundar a reflexão sobre margens, ver Rosa (2018). 
Muitas vezes, a produção científica sobre esses territórios assume ações 'extrativistas', com intenções intervencionistas e higienistas, tomando-os apenas como ‘objetos de estudo'. Enquanto isso, as pessoas deles advindas não são acolhidas como sujeitos políticos e encontram dificuldades para acessar a universidade e/ ou ter seus conhecimentos validados por ela, quando assim desejam. Assim, a histórica invisibilização da presença de pessoas negras "contrasta com a vasta produção acadêmica que irá se desenvolvendo em torno dessa nova condição de objeto de estudo" (CARNEIRO, 2005, p. 57).

Na última década, no entanto, um número crescente de estudantes negras e moradoras de territórios populares e negros ingressaram na universidade e tiveram acesso à pesquisa a partir de políticas públicas de reparação histórica, como as cotas raciais - alcançadas através da constante luta dos movimentos sociais, sobretudo dos movimentos negros -, e/ou dos esforços das suas familiares, que apostaram na melhoria de vida com investimentos na educação. Quando ingressam, muitas vezes são, como nós, as primeiras pessoas de suas famílias e/ou territórios a ter acesso à universidade e contato com a pesquisa científica.

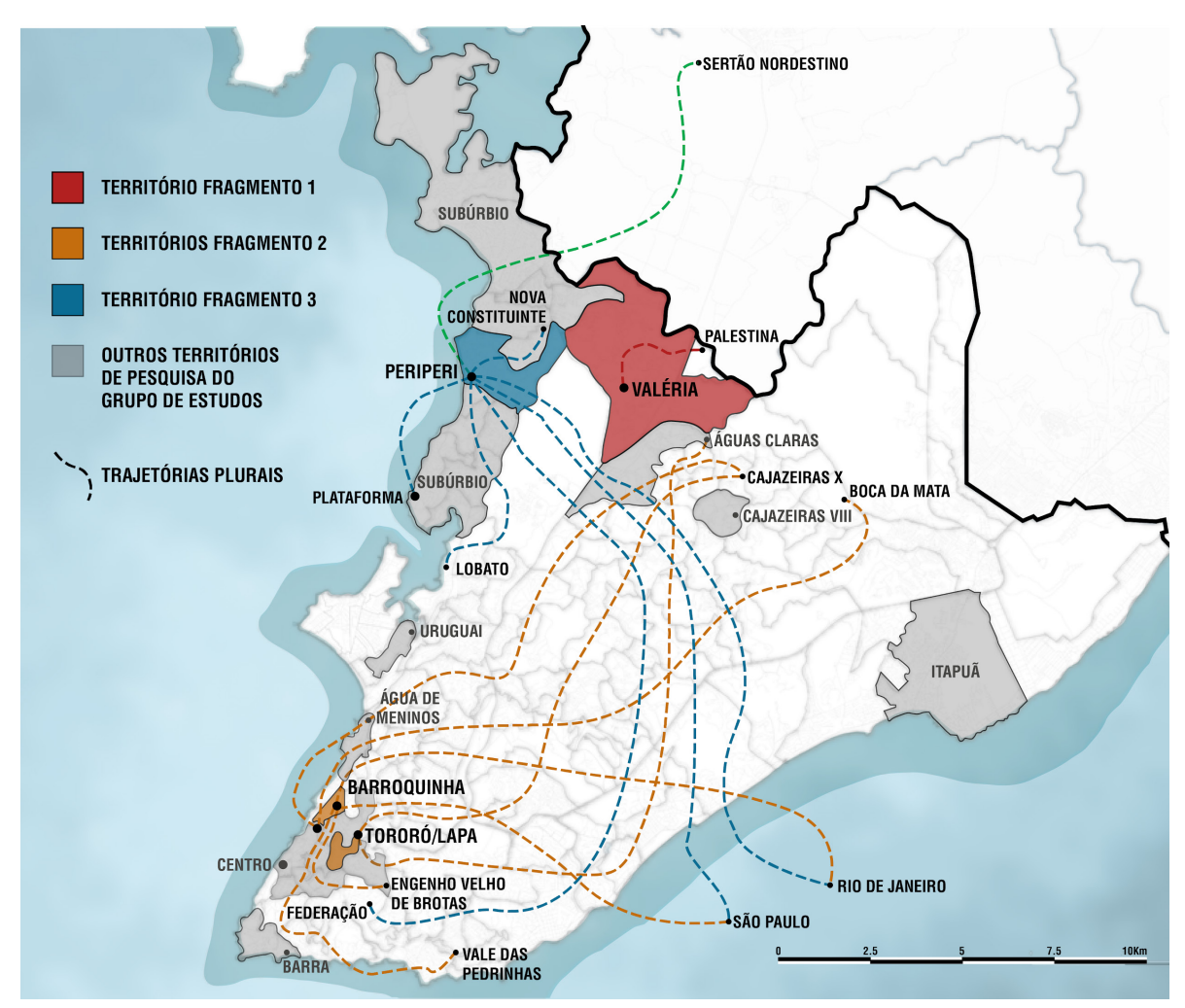

Figura 2. Territórios de pesquisa do grupo de estudos Margear Fonte: Acervo do grupo de estudos Margear. Autoria coletiva, 2021. 
Diante disso, uma condição de pesquisa implicada (MACEDO; MACEDO DE SÁ, 2018) torna-se necessária; nela, por meio de experimentações metodológicas e articulações entre teoria e empiria, produz-se ciência no cotidiano, em diálogo com as disputas urbanas em curso nas cidades brasileiras, que são profundamente desiguais. Ou seja, a pesquisa implicada não é apenas uma opção teórico-metodológica, mas também um fundamento ético e político.

Na dobra cidade-universidade, evidenciam-se os múltiplos processos do fazer-cidade, uma “expansão contínua dos universos sociais e urbanos” (AGIER, 2015, p. 491) que se conformam entre o que se consolidou chamar de autoconstrução popular do espaço urbano e as intervenções institucionais públicas e privadas. 0 termo fazer-cidade é empregado com vistas a englobar práticas e saberes que também constituem as cidades, para além daqueles institucionalizados ou vinculados à prática profissional de arquitetas e/ou urbanistas.

Compartilhamos aqui provocações, experiências e fragmentos construídos desde e com diferentes territórios populares e negros soteropolitanos, abarcando historicidades, memórias, epistemologias e redes de sociabilidade heterogêneas. Na Figura 2 destacamos, com cores distintas, os territórios correspondentes a cada fragmento, assim como outros territórios de pesquisa do grupo que não foram mencionados neste texto, mas que igualmente alimentam as considerações aqui trazidas. O mapa mostra, ainda, os diferentes territórios populares e negros atravessados pelas trajetórias urbanas ${ }^{5}$ das interlocutoras, constituindo, assim, um "repertório de lugares” (RATTS, 2001, p. 114).

\section{Fragmento: Mulheres, memórias e espaços ${ }^{6}$}

É difícil lembrar de espaços em que cresci que não estivessem centralizados nas matriarcas, por isso, as tenho como figuras centrais na perpetuação das memórias e dos espaços de vida. Escutar as histórias dessas mulheres negras me faz compreender quem construiu a mim mesma e quem construiu o bairro de Valéria, onde nasci e fui criada.

Valéria é um bairro de mulheres. De origem essencialmente rural, é reflexo de boa parte dos territórios da Bahia, onde é comum a matriarcalidade negra, na

5. As trajetórias urbanas têm sido, para muitos estudos do grupo, fonte de reflexões sobre o fazer-cidade na articulação entre escalas. Para uma discussão mais pormenorizada, ver: TELLES, V. S.; CABANES, R. (Org.). Nas tramas da cidade: trajetórias urbanas e seus territórios. São Paulo: Associação Editorial Humanitas, 2006.

6. Esse fragmento faz parte da pesquisa de Zara Rodrigues, desenvolvida como Trabalho Final de Graduação. Para se aprofundar mais nesse território e pesquisa, ver: SILVA, Z. P. R. Histórias de Valéria: Fragmentos de Memória e Imaginação, 2020. Disponível em: https://www.historiasdevaleria.com. Acesso em: 15 dez. 2021. 
qual a mulher é figura estruturante dos modos de ser, habitar e viver (HITA, 2014). Essa qualidade ancestral atrai, principalmente para elas, a função de protetoras da memória. Mesmo inconscientemente, são elas as mais envolvidas na construção de redes de sociabilidade e nos atos de cuidado, produzindo espaços para além da casa. Todas juntas, ocupando lugares no labor e no lazer diário, fazendo cidade.

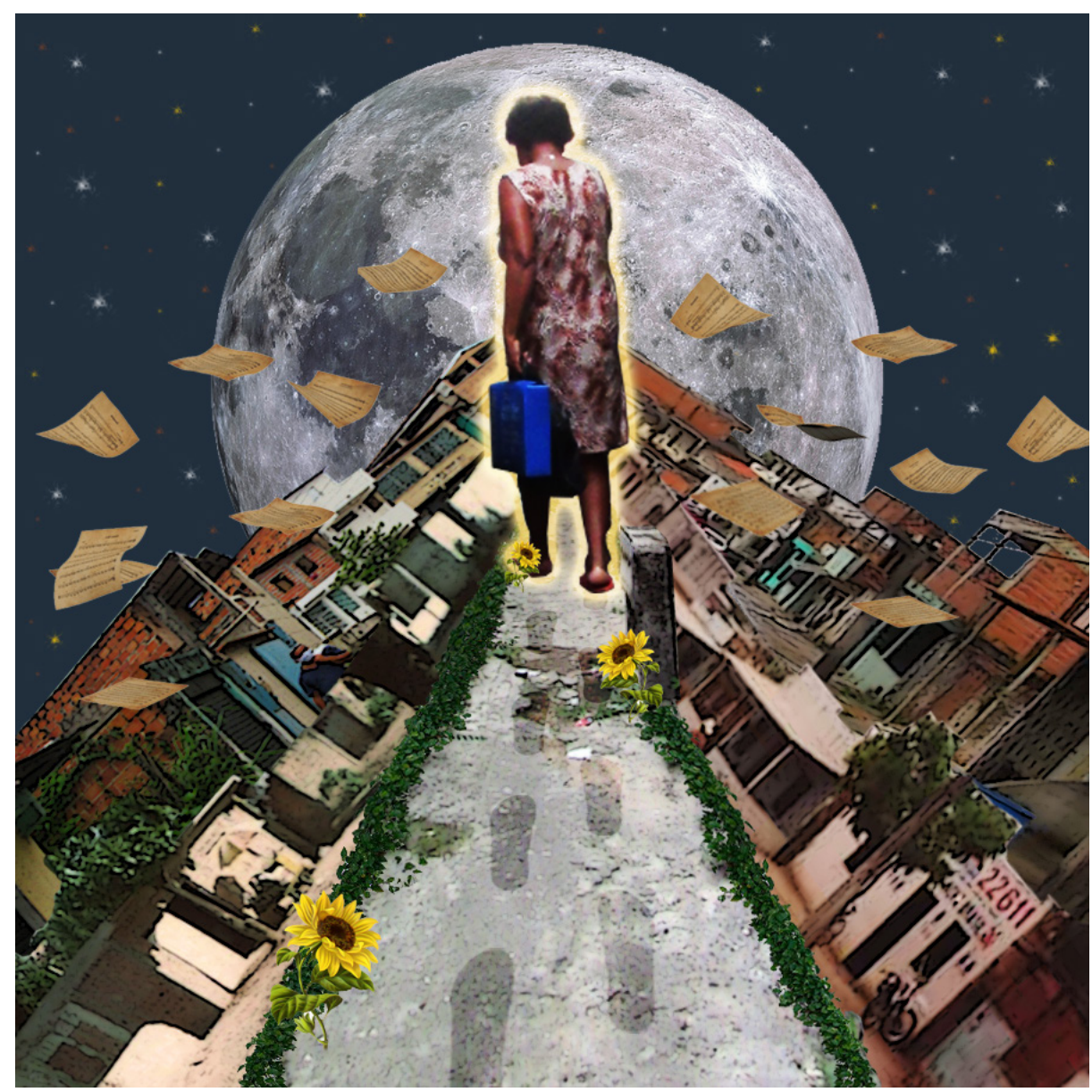

Figura 3. Os caminhos de Dona Nita

Fonte: Acervo do grupo de estudos Margear. Autoria de Zara Rodrigues, 2020.

A mulher mais velha com que conversei, Dona Nita (67 anos), possui memórias muito vivas de sua trajetória, as quais, como as da minha família, se mesclam à própria história do bairro (Figura 3). São evidentes as ações fortemente coletivas e colaborativas em suas vivências da infância até a vida adulta, das brincadeiras de roda na frente de sua casa às latas d'água na cabeça para os afazeres domésticos, além do protagonismo na igreja católica, que lhe proporcionou muitas conexões com a comunidade, e da liderança comunitária, como a atuação na antiga Associação de Moradores. Decerto, não ignoro o quanto a memória pode ser cheia 
de desvios e omissões, sendo tudo isso passível de interpretação. Como Dona Nita afirma: "eu lembro de tudo, mas alguma coisa o miolo cozinhou de velhice, né?!”. Cabe compreender que, por mais que os diálogos sejam intensos e muito informativos, são um recorte do que a memória se propôs a trocar; a partir disso, é preciso fabular interpretações diacrônicas (BOSI, 2003).

A memória é fragmentada, nunca está pura ou límpida. Mbembe (2019) afirma que isso é fruto da própria experiência de colonização dos nossos povos, que em algum momento tiveram suas memórias quebradas, sendo impossível reconstituí-las em sua unidade original. Desse modo, se comportam como colagens.

Ao elaborar a subjetividade desses relatos, o que mais me chama a atenção é o valor de acervo que lhes é intrínseco e o quanto essas memórias estão marcadas por ranhuras sociais que podem ser sinônimo de luta por afirmação e/ou, ao contrário, de total desesperança. Por isso, afirmar essas memórias e perceber nossos corpos performando modos de ascender frente às desigualdades é um ato político (MARTINS, 2003).

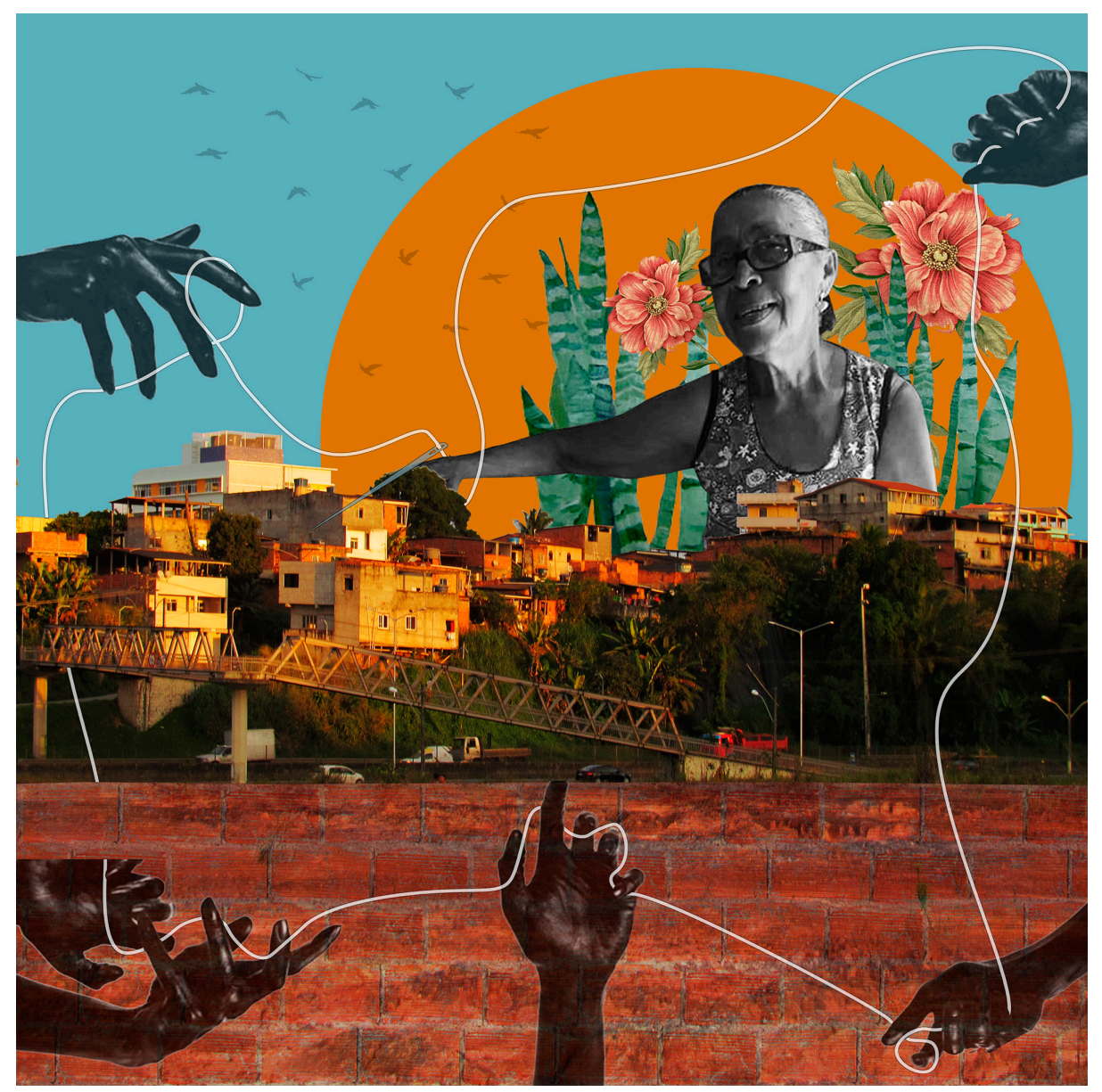

Figura 4. A Palestina é resistência e Valéria também

Fonte: Acervo do grupo de estudos Margear. Autoria de Zara Rodrigues, 2020. 
Do cuidado com a casa ao cuidado com as fontes d'água, das brincadeiras de roda aos movimentos de luta por afirmação, as articulações das mulheres de Valéria são sinônimo de um modo de vida comunitário (Figura 4). Afirmar esses modos de vida femininos e negros, em comunidade, é afirmar a nossa própria história. É um ato de enraizamento (WEIL, 1996).

\section{Pesquisa implicada desde e com as margens}

Ao investigar os "espaços de pobreza" a partir do adensamento populacional das cidades brasileiras na década de 1960, os campos de estudos urbanos consolidaram categorias analíticas dicotômicas (ROSA, 2009; 2018) e, em alguns casos, naturalizaram formas distanciadas de produção de conhecimento sobre as cidades. Hoje, de maneira geral, as produções de conhecimento na esfera acadêmica continuam pautadas em ideias totalizantes e supostamente universais de cidade, constituídas com base em um referencial teórico colonialista e eurocêntrico (RAMOS, 2013). Quando a análise está voltada a territórios tidos/lidos como "pobres”, "populares”, a dimensão problemática aparece predeterminada como "um dado objetivo que estaria presente qualquer que fosse a situação ou o ângulo de análise” (ROSA, 2018, p. 193).

No âmbito local, no campo disciplinar do urbanismo, não é raro que produções acadêmicas sobre Salvador, cidade fundada a partir da diáspora forçada de povos africanos e da infraestrutura escravista (FIGUEIREDO; ESTÉVEZ; ROSA, 2020), ainda importem preceitos e formas de pensar e pesquisar cidades informados pelo referencial da modernidade, da colonialidade ${ }^{7}$ e da branquitude ${ }^{8}$, desprezando e/ ou invisibilizando, consequentemente, os processos de produção de cidade pela negritude (PEREIRA, 2018). Logo, pensar a relação entre o fazer-cidade e os modos de vida dos agentes desse processo passa por entender que o paradigma moderno suprimiu, ou tentou suprimir, outros ${ }^{9}$ modos de vida e de fazer-cidade. Nos estudos urbanos, há a carência de uma ampla difusão de referências nordestinas que se aproximem da cidade e das vidas que a fazem de uma perspectiva interseccional (AKOTIRENE, 2019; GONZALEZ, 2020). Apesar da baixa reverberação de produções

7. Sobre colonialidade, ver: RIVERA CUSICANQUI, S. Ch’ixinakax utxiwa: una reflexión sobre prácticas y discursos descolonizadores. 1. ed. Buenos Aires: Tinta Limón, 2010.

8. Sobre branquitude, ver: BENTO, M. A. S. Pactos Narcísicos no racismo: Branquitude e poder nas organizações empresariais e no poder público. 169p. Tese (Doutorado) - Instituto de Psicologia da Universidade de São Paulo. 2002; SCHUCMAN, L. V. Entre o "encardido", o "branco" e o "branquíssimo": Raça, hierarquia e poder na construção da branquitude paulistana. Tese (Doutorado) - Programa de Pós-Graduação em Psicologia, Instituto de Psicologia da Universidade de São Paulo, 2012.

9. A dimensão da alteridade e a ideia de outros modos de vida, de fazer-cidade, e de outras histórias são abordadas aqui em relação à cidade e às formas de pesquisar e narrar dos estudos urbanos. Para importantes reflexões nesse sentido, ver Carneiro (2005). 
científicas deslocadas da centralidade Rio de Janeiro/São Paulo, elas existem e merecem destaque, a exemplo das reflexões dos grupos de pesquisa Etnicidades ${ }^{10} \mathrm{e}$ Corpo, Discurso e Território"1, ambos vinculados à FAU/UFBA e ao PPGAU/UFBA.

O recorte de classe foi historicamente priorizado nas produções que mais circularam nos estudos urbanos brasileiros desde a segunda metade do século passado. Elas analisaram o fazer-cidade a partir do distanciamento e da ausência do léxico racial, ancoradas em noções nas quais “a 'classe trabalhadora' foi claramente entendida como um corpo branco, uma episteme universal e um modo de vida unívoco" (FIGUEIREDO; ESTÉVEZ; ROSA, 2020, p. 58, tradução nossa) ${ }^{12}$. De fato, essas produções mistificam a história social negra, não reconhecendo a constância do conflito racial e sua dimensão estrutural. Há uma desvalorização de seus agenciamentos, insurreições e tecnologias sociais, com a produção de um entendimento sobre a população negra como grupo a-histórico (MOURA, 1983). Frequentemente, até mesmo perspectivas que levam em conta o gênero como condicionante da experiência na cidade desconsideram que gênero não é uma categoria universal, estável e descontextualizada (CURIEL, 2007) ${ }^{13}$.

McKittrick (2011) argumenta que a negação da existência espacial é uma dimensão da desumanização promovida pela opressão racial. Analisando negritude, espaço e lugar durante a escravidão, a autora revela que pessoas negras escravizadas eram consideradas como corpos que não deveriam existir na paisagem - isso é o que Lélia Gonzalez designou “divisão racial do espaço”, tendo como separação física o espaço ocupado por dominadores e dominados (GONZALEZ; HASENBALG, 1982). Nesse sentido, McKittrick (2011) nos chama a atenção para como as análises de espaço e racialidade muitas vezes são paralisadas pela narrativa do corpo negro sofredor. Essa lógica analítica determina a morte negra como único fim e, curiosamente, refaz as estruturas coloniais contra as quais as pesquisas estariam, aparentemente, trabalhando, replicando discursos de violência antinegras nos estudos acadêmicos.

10. Para se aprofundar na produção do grupo de pesquisa Etnicidades, ver: https://etnicidadesufba. blogspot.com/p/apresentacao.html.

11. Para se aprofundar na produção do grupo de estudos Corpo, Discurso e Território, ver: https://medium.com/@gcorpo.discurso.territorio.

12. No original: "The 'working class' have clearly been understood as a white body, a universal episteme and a univocal way of life." (FIGUEIREDO; ESTÉVEZ; ROSA, 2020, p. 58).

13. Em contraponto, o site FeminismUrbana (https://feminismurbana.wordpress.com/) divulga produções, imagens e eventos que dialogam com a perspectiva de gênero e cidade no Brasil e na América Latina. Destacamos ainda as teses das administradoras da página, que trazem a perspectiva do gênero para o debate urbano: HELENE, D. R. "Preta, pobre e puta": a segregação urbana da prostituição em Campinas - Jardim Itatinga. Tese (Doutorado) - Programa de Pós-Graduação em Planejamento Urbano e Regional, Universidade Federal do Rio de Janeiro, 2015; TAVARES, R. B. Indiferença à diferença: espaços urbanos de resistência na perspectiva das desigualdades de gênero. Tese (Doutorado) - Programa de Pós-Graduação em Urbanismo, Universidade Federal do Rio de Janeiro. 2015. 
Temos buscado ultrapassar uma percepção homogeneizada, voltando-nos para as complexidades que formam os territórios populares e negros. A esse respeito, Simone (2004) contribuiu para pensarmos como a autorresponsabilidade pela sobrevivência urbana deu abertura para diferentes formas de organizar o espaço. O autor elabora a ideia de "pessoas como infraestruturas", estendendo a noção de infraestrutura para além dos componentes físicos ao incorporar diretamente as atividades das pessoas que provêm meios para tornar a cidade produtiva, reproduzindo e posicionando seus residentes, territórios e recursos.

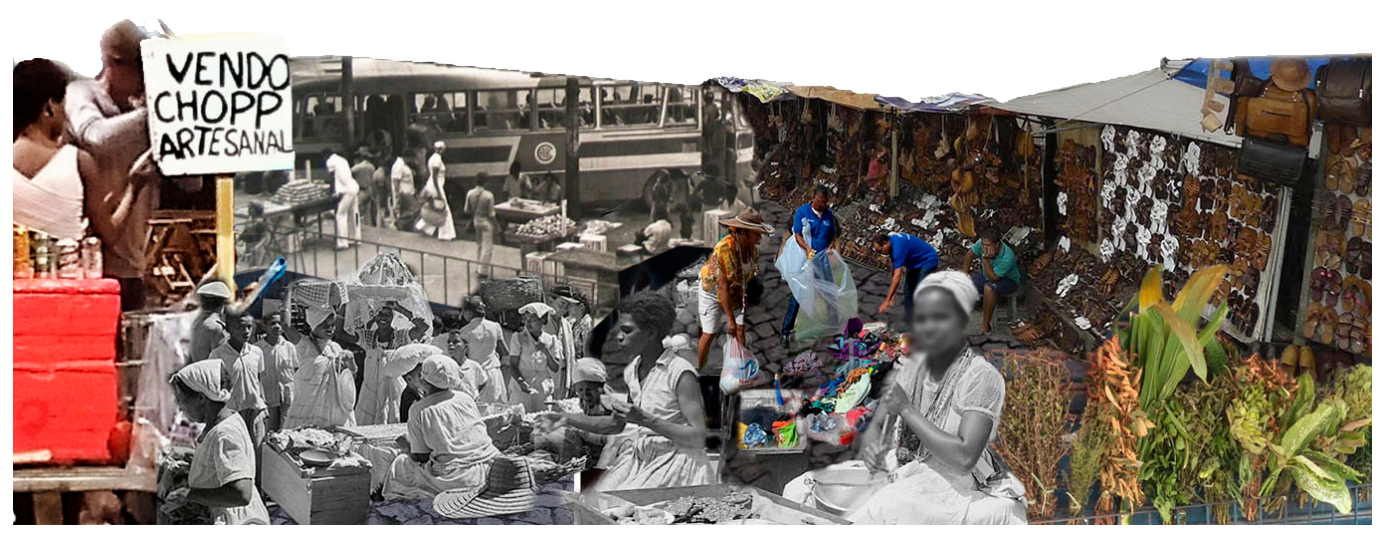

Figura 5. Modos de fazer urbanos e ancestrais

Fonte: Acervo do grupo de estudos Margear. Autoria de Aleida Batistoti, 2020.

Essas perspectivas incidem sobre modos de vida de pessoas negras, comunidades tradicionais e práticas de trabalho (como trabalhadoras de rua, pescadoras e marisqueiras) que, muitas vezes, são vistas exclusivamente pela chave da 'ausência' e 'escassez', numa percepção reificada e estigmatizante a respeito delas. No entanto, não desconsideramos as precarizações, as fragilidades e a falta de políticas públicas urbanas que prejudicam a existência de melhores condições de vida a esses grupos. De forma crítica e política, propomo-nos a identificar essas presenças negras através também da potência, evidenciando suas contribuições para as disputas urbanas e para outras possibilidades do fazer-cidade (Figura 5). E fazemos isso porque ainda carecemos da criação de um arcabouço teórico no campo dos estudos urbanos ${ }^{14}$ que evidencie as potencialidades, tecnologias criativas e infraestruturas desenvolvidas por pessoas que, histórica e cotidianamente,

14. Cientes de que, apesar de escassas, estão sendo produzidas importantes reflexões, destacamos algumas delas nas notas de rodapé. Mesmo que não as tenhamos citado no corpo do artigo, julgamos fundamental trazê-las, pois contêm pistas significativas dos rumos que os estudos sobre cidade vêm tomando. 
constroem seus territórios e dimensões relevantes para a reprodução da vida em sociedade (PEREIRA, 2019).

As trajetórias urbanas de mulheres negras têm sido essenciais para pensarmos o fazer-cidade na microescala, como evidenciado nos fragmentos e imagens, em função dos agenciamentos que elas realizam: trabalho, moradia, família, redes de cuidado e de afeto, assim como conflitos, disputas e violências. Suas trajetórias nos permitem descrever a cidade, pois evidenciam disputas travadas no cotidiano (ROSA, 2014), nas quais elas têm ampla participação, já que frequentemente se encontram na linha de frente dos conflitos urbanos, por serem as mais atingidas pelas políticas excludentes de projetos institucionais (HELENE, 2019).

\section{Fragmento: disputas urbanas, trabalho de rua e moradia'5}

Foi a forte presença de mulheres negras trabalhando nas ruas ${ }^{16}$ de Salvador que fez com que nos lançássemos ao encontro delas: nas ruas e nas casas, experienciando com elas seu dia a dia, suas relações de trabalho e vizinhança, momentos amenos e também de conflito, dias de chuva e de sol quente, abordagens do "rapa"17, correria, alguns dias cheios de boas conversas e outros, de silêncios. Cida, Dália e Tânia, mulheres negras com trajetórias diversas, atravessadas por deslocamentos ao longo de uma vida em busca de trabalho e moradia mais dignos, idas e vindas marcadas pela luta e resistência. Como mulheres negras, o trabalho sempre esteve presente em suas vidas, desde muito cedo, em "casas de família” ou acompanhando as mães - "Eu não trabalhava assim, mas eu lavava uma roupa, já fazia assim uma faxina, já não ficava parada, não". Se estabeleceram no trabalho de rua como alternativa de sustento, dentro das possibilidades e/ou impossibilidades, mas sempre guiadas por imaginações de futuros outros.

Ambulantes há quase 40 anos, elas ocupam diferentes locais - uma rua, uma praça, uma estação de transporte público, todos no centro de Salvador. Vivenciando requalificações, reformas e remoções de projetos urbanísticos que incidem diretamente em suas práticas de trabalho e/ou territórios de atuação e moradia. “Esse pedaço de terra aqui, a gente aqui 'invadiu' cinco vezes e não ficou, tirava,

\footnotetext{
15. Esse fragmento faz parte da pesquisa de mestrado, em andamento, de Aleida Fontoura Batistoti. A dissertação trata do trabalho de rua praticado por mulheres negras no centro ampliado de Salvador/BA.

16. Utilizamos o termo "trabalho de rua" para as práticas de trabalho e o termo "ambulante" para as mulheres que o praticam. Essas escolhas se baseiam na pesquisa bibliográfica e na apreensão dos modos de enunciação e autodeterminação das próprias mulheres interlocutoras.

17. "Rapa” é uma noção generalizada entre as trabalhadoras de rua do Brasil. Trata-se de práticas de repressão ao trabalho de rua, podendo ser efetuadas por diversos agentes, como guardas municipais, policiais, fiscais da prefeitura, entre outros. Em Salvador, os fiscais da Secretaria Municipal de Ordem Pública (SEMOP) efetuam os "rapas".
} 
a SUCOM [atual Secretaria Municipal de Desenvolvimento e Urbanismo (SEDUR)] chegava e tirava, cinco vezes". Nas tentativas de remoção, sempre disputam a permanência para preservar seus vínculos, redes e clientes, afirmando o centro como território negro e popular (FIGUEIREDO; ESTÉVEZ, 2020); muitas vezes conseguem voltar a ocupar o território, ainda que nas margens. "Queria tirar a gente, eles não tiraram porque brigamos muito. E brigamos e provamos. Agora mesmo, com essa retirada dessa reforma daí. Não tinha intenção de botar a gente em lugar nenhum". As violações não se encerram nos projetos, elas são submetidas à constante repressão do "rapa”, da apreensão de mercadorias a violências físicas e psicológicas, que miram as mulheres, em especial (OBSERVATÓRIO DAS METRÓPOLES, 2019). "Esse pessoal quando chega assim, trouxe polícia, trouxe guardinha, trouxe o carai todo que eles queriam, parecia que a gente era ladrão. Meteu foi a máquina aí, pisou no caralho aí, que nada [...]"

Atingidas pelos processos estruturantes de cidade, elas se colocam ativamente frente aos projetos urbanos institucionais. A partir do estabelecimento de relações com o meio em que estão inseridas, criam redes, articulações políticas e tiram proveito do vigor e do dinamismo desses espaços (ITIKAWA, 2016). No fazer-cidade cotidiano, ocupam as ruas, promovem novos usos e as transformam a cada dia e a cada ocupação. Em suas trajetórias, tensionam lugares e imaginários preconcebidos do que seja o trabalho de rua, reivindicam reconhecimento e respeito, reafirmam suas conquistas alcançadas com luta e trabalho árduo.

Aí, eu construí [a casa] com o dinheiro daqui, dinheiro que proporcionou meus filhos a estudarem bem, sabe? De ter carro, de viajar. Tem gente que ficava surpreso que via a gente aqui trabalhando, aí quando a gente fazia festinha de aniversário alguma coisa 'mas vocês moram assim?' Entendeu? 'Você tem mais de uma TV', coisa assim, que pra gente é natural, mas eles achavam que a gente vivia de outra forma, entendeu? E a gente nunca achou estranho ter, porque a gente trabalhava e ganhava para isso.

Casa-depósito - casa-terreiro - casa-andar: as trajetórias e narrativas dessas mulheres evidenciam que a casa vai muito além do local de morada ou repouso. Movimentam relações profundas com as mulheres que as habitam, permeando suas histórias e processos de vida, firmando marcas, alimentando sonhos e desejos, cruzando cotidiano, trabalho, religiosidade, família e ancestralidade. Dimensões da vida e do cotidiano materializam-se e emaranham-se nessa relação casa-trabalho-corpo. Assim, considerando que as práticas econômicas não são dimensões apartadas da vida (MOTTA, 2016), em especial para as mulheres e suas 
moradias, vemos os arranjos e táticas que se cruzam na gestão do trabalho e da vida, como ocorre com as "guias"18: "a guia é nossa vida, a gente não pode deixar ela acabar, é com a 'guia' que nos alimentamos, se tem 'guia' não passa fome, paga as contas". A "guia" é um instrumento de trabalho, é um modo de vida que possibilita o dinheiro girar, nutrir e sustentar, proporcionando projeções futuras. Foi a partir da "guia" que Dália e Tânia construíram suas casas: "eu trabalho duas semanas para 'guia' e duas semanas para mim. Porque nós estamos construindo”.

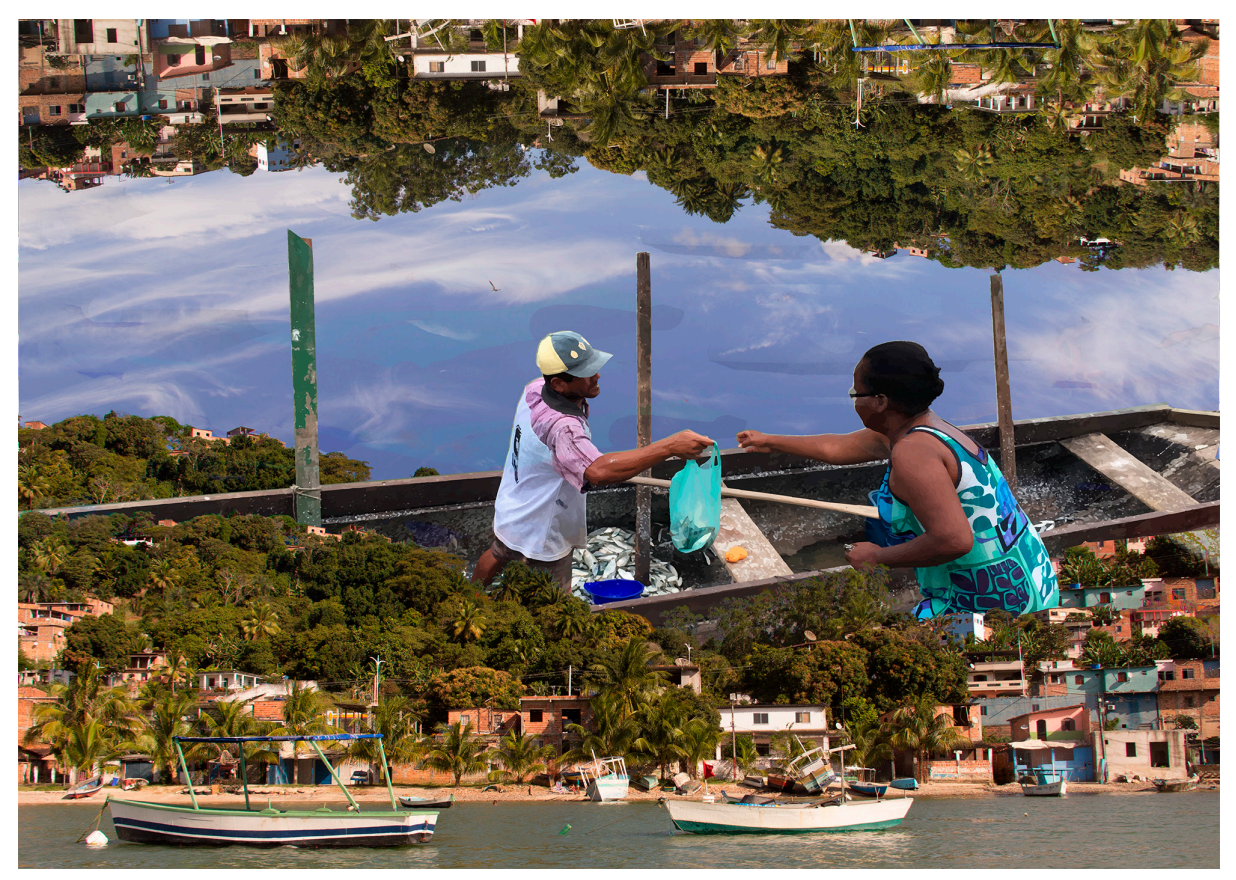

Figura 6. Cotidiano suburbano: luta e criação

Fonte: Acervo do grupo de estudos Margear. Autoria de Atailon Matos, 2020.

As mulheres ocupam um lugar significativo na gestão do universo social das casas. Elas são as responsáveis pelos circuitos, trocas e movimentos no cotidiano da moradia com as demais camadas da vida (PINHO, 2019). Ocupam esse lugar não em oposição ao espaço público; pelo contrário, as mulheres ambulantes rompem esse imaginário dicotômico nas práticas cotidianas construídas em relação às outras casas, à economia, às políticas de cuidado e ao afeto (Figura 6).

18. A “guia” é usualmente atribuída aos produtos e instrumentos de trabalho que possibilitam a ocupação da rua e a realização da atividade. Para as mulheres, a "guia" é um modo de vida, articula dimensões do cotidiano, proporciona autonomia, sobrevivência, a projeção e realização de desejos, como ter uma casa própria e criar os filhos. 
5 Como construir metodologias e narrativas a partir do encontro entre diferentes corpos?

$\mathrm{Na}$ tentativa de construir pesquisas que levem em conta nossas inquietações, estamos propondo experimentações teórico-metodológicas e inter/transdisciplinares que contribuam para as lutas contra os apagamentos e interdições reiterados pela academia. Essas premissas fazem parte da construção de uma episteme dialógica, prática enunciada por Ribeiro (2010), que se concretizaria em uma implicação corpórea das pesquisadoras, uma "disposição aos encontros, ao diálogo [...] à partilha de saberes e produção conjunta de conhecimento com aquelas que habitam e produzem cotidianamente as margens da cidade” (ROSA, 2018, p. 192). É nesse sentido que é importante a atenção às perspectivas das mulheres negras, que, apesar de ocuparem posições marginais no meio acadêmico, como outsiders within (COLLINS, 2016), têm feito uso criativo de sua marginalidade, enunciando pontos de vista que trazem provocações e contribuições cruciais às análises da academia.

Para além da produção de pesquisadoras negras dentro da universidade, as trajetórias, narrativas e memórias de nossas interlocutoras somam importantes camadas à produção de conhecimentos. É nos encontros de pesquisa (FELTRAN, 2011; ROSA, 2014), com e entre mulheres, que temos construído nossas investigações, a partir de relações que vão se tecendo através da proximidade e dos afetos estabelecidos em uma temporalidade alargada. Por meio da confiança construída entre pesquisadoras e interlocutoras, assuntos até então não abordados começam a surgir; vêm à tona relatos cotidianos, a partir dos quais é possível apreender as trocas e relações do dia a dia. Os encontros se dão nos diferentes contextos que permeiam as pesquisas - casa, rua, quintal, praia, trabalho, lazer, espaço público - e proporcionam afetações em nossos corpos, assim como de nossos corpos no território.

Os encontros, como método, destacam que a teoria raras vezes é fruto de um processo individual, na verdade, frequentemente nasce de um envolvimento com fontes coletivas (HOOKS, 2017). Contudo, esse fazer coletivo exige diálogo, sensibilidade, um agir ético e com respeito, pois a produção compartilhada de conhecimento nos coloca diante de uma série de complexidades, seja na construção de uma relação com as interlocutoras, ao adentrar territórios nos quais somos estrangeiras, seja na observação de territórios que nos são familiares - a alteridade pode acionar dores e memórias ${ }^{19}$. Diante disso, precisamos encarar o fato de que nossos corpos e práticas de pesquisa também são potenciais reprodutores das violências contra as quais argumentamos. Na vivência dos processos de pesquisa, enfrentamos

19. Entendemos que os efeitos do escravismo e genocídio dos povos africanos e originários, bem como os processos tortuosos de enfrentamentos, permanecem nas memórias ancestrais de suas descendentes, encarnados em seus corpos (CARNEIRO, 2005). 
atravessamentos em diferentes escalas, tanto por fazermos parte de grupos sociais cuja produção de conhecimento é recorrentemente desconsiderada pelas epistemologias dominantes e/ou institucionalizadas, quanto por nos depararmos com tais interdições, buscando caminhos que não compactuem ou colaborem com sua perpetuação. Com um desejo de implicação radical, como convocado por Cíntia Guedes (IHAC, 2020), realizamos nossas pesquisas não porque objetivamos apenas oferecer solidariedade às interlocutoras e territórios, mas porque entendemos que chegamos ao esgotamento do modelo ético político em que vivemos - aliás, nossas próprias vidas dependem de sua mudança.

Um dos caminhos que vêm sendo construídos coletivamente são as trocas inter/transdisciplinares, em diálogo, por exemplo, com produções da antropologia, da história, das artes, da geografia. Desse modo, uma aproximação cautelosa com a etnografia como campo epistemológico tem nos ajudado - etnografia entendida tal como Peirano (2014, p. 385), isto é, como produção/contribuição teórica, e não um mero "detalhe metodológico". A antropóloga Montoya Uriarte (2013) problematiza ainda a ideia de que o nosso olhar é fabricado ou mesmo domesticado para ver determinadas coisas em detrimento de outras no espaço urbano, um olhar que, na velocidade e na rotina, acaba por "achatar" a realidade observada. Por meio dessa aproximação, adotamos, então, o exercício de "fabricar um olhar para ver a cidade” (URIARTE, 2013, p. 12) de forma consciente, crítica, perseverante, sensível.

Em diálogo com a história, em suas aproximações e tensionamentos com a memória e a oralidade, buscamos elaborar histórias outras dos territórios populares e negros, de modo a contrapor narrativas oficiais excludentes ou mesmo incompletas. Paoli (1992, p. 26) defende que dar visibilidade a essas narrativas é uma postura que "se apoia na possibilidade de recriar a memória dos que perderam não só o poder, mas também a visibilidade de suas ações, resistências e projetos”, construindo políticas "que repouse[m] no reconhecimento do direito ao passado enquanto dimensão básica da cidadania”. Considerando isso, o próprio processo de interlocução da pesquisa possibilita que essas histórias sejam contadas e ouvidas, além de direcionadas para lugares que normalmente elas não ocupam, como a universidade.

Desse modo, álbuns de família e fotografias de acervos tornam-se não apenas fontes, mas também ferramentas de pesquisa. Como estratégia de mediação em interlocuções, por exemplo, utilizamos fragmentos encontrados em acervos institucionais que dizem respeito à história do território estudado ou manuseamos os álbuns de fotografia das famílias das interlocutoras. E, ainda, assim como Duarte e Gomes (2008), visitamos nossos próprios álbuns de família como pesquisadoras-moradoras, usando as imagens como disparadoras de memórias, o que nos possibilitou observar momentos que nunca vivemos, mas que são relevantes em nossas 
histórias familiares. Além da possibilidade de estabelecer diálogos estratégicos com essas histórias, tecemos conexões entre as trajetórias individuais e as dimensões coletivas do fazer-cidade.

Em diálogo com Azoulay (2019), enfatizamos que as imagens não são politicamente neutras, nem se ausentam das relações de poder entre os corpos que participam de sua constituição. Assim sendo, a cultura visual é "produto e produtora de discursos materializados e corporificados, marcada por relações de poder, por inscrições inconscientes e por experiências estético-afetivas” (TVARDOVSKAS; NAVARRO-SWAIN, 2020, p. 114). Na cultura ocidental, as imagens são constrangidas a comunicar, "domadas e controladas" (MORTIMER, 2018, p. 163), submissas à escrita que tenta explicá-las, logo, enquadrá-las como ilustrações. Como propõe Mortimer (2017; 2018), apostamos no potencial que as imagens possuem de agitar estruturas estáveis, especialmente aquelas que tangenciam os preceitos do campo dos estudos urbanos no país, dado que, através de imagens insubmissas ao controle da escrita, se conforma um território de disputa por visibilidade.

Alertamos que os fragmentos textuais aqui trazidos não se propõem a esgotar os sentidos das imagens mobilizadas e seus distintos processos de construção. Experimentamos estratégias de narração como possibilidade para estabelecer diálogos a partir de variadas composições e diferentes formatos, de modo a documentar, visibilizar, reconstruir e refletir sobre as formas de fazer-cidade que as margens evocam. Apesar de a produção acadêmica ainda privilegiar a escrita em detrimento de demais linguagens (HOOKS, 2017), utilizamos fotografias, colagens, cartografias, áudios, vídeos, entre outros, como processo reflexivo e, ao mesmo tempo, como ferramenta para socializar nossos resultados através de múltiplas expressões (Figura 7).

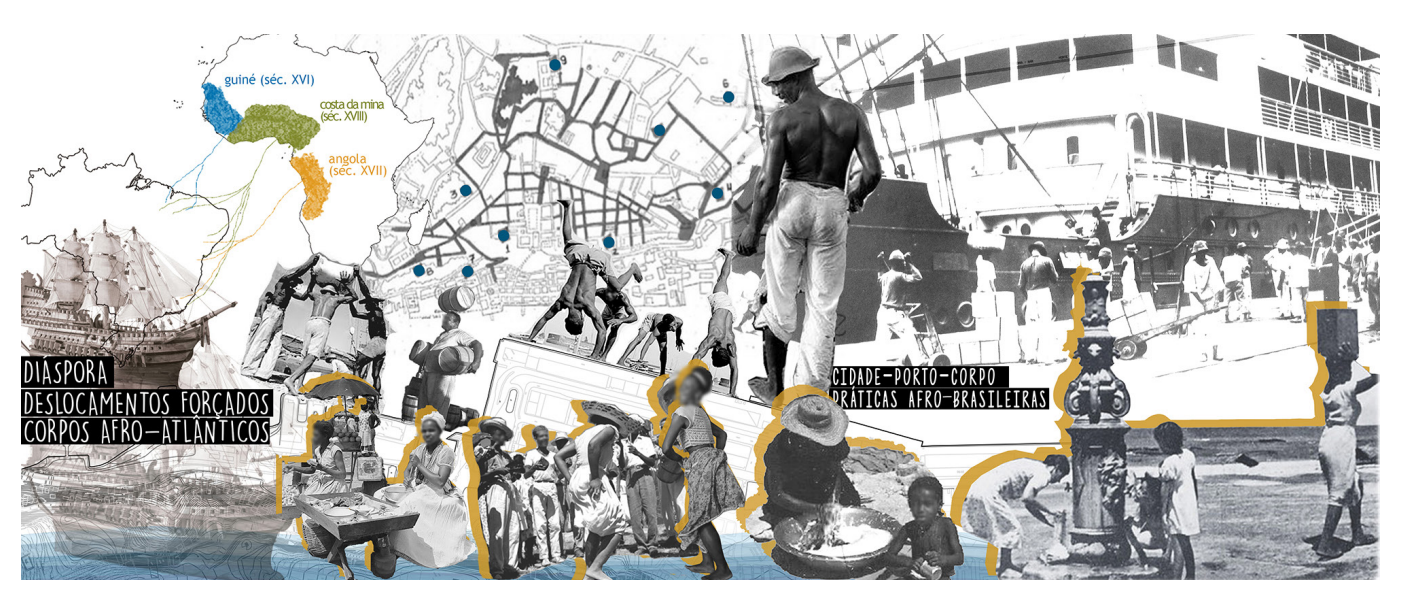

Figura 7. Corpo-porto-cidade

Fonte: Acervo do grupo de estudos Margear. Autoria de Aleida Batistoti, Ingrid Pita e Yago Souza, 2019. 
A produção de narrativas imagéticas busca contestar as representações estabelecidas de determinados temas. A partir da sobreposição de fragmentos de variadas fontes, pretendemos criar narrativas que comuniquem distintas temporalidades, um cruzamento entre memórias, tempo presente e imaginações de futuros. Almejamos, com esses variados modos de narrar, abrir caminhos imaginativos em torno dos territórios populares e negros, a fim de rompem com as projeções de extermínio para eles programadas. Compilando referências imagéticas e materiais, intentamos alimentar, ainda, a coconstrução de acervos que suscitem narrativas outras sobre esses territórios.

Ao construir tais narrativas desde as margens da universidade e da cidade, consideramos ser possível amplificar o alcance do conhecimento produzido, potencializando não apenas a difusão científica, em defesa de sua universalização, mas também a construção de reflexões e ações críticas que possam ir além da universidade, alcançando estudantes, pesquisadoras e moradoras, sobretudo mulheres e pessoas negras que ocupam e fazem as margens, a partir das quais e com as quais as pesquisas querem dialogar.

\section{Fragmento: territorialidades e trajetórias aquosas ${ }^{20}$}

Foram as atuais, e cada vez mais constantes, intervenções urbanas institucionais ${ }^{21}$ em Periperi que nos aproximaram desse bairro do Subúrbio Ferroviário de Salvador (Figura 8).

Em sua orla, as primeiras interlocuções se dão com homens negros, moradores, pescadores. Durante a semana há uma quietude, algumas pessoas tomam banho nas águas calmas, quase não há fregueses nos bares, alguns sequer abrem, pescadores transitam em mar e em terra vendendo a pesca para os donos dos bares, que irão vender para a freguesia no fim de semana. Este sim é agitado. A Associação Velha Guarda de Futebol realiza seus torneios; jogadores de futebol, que frequentam a praia desde que nasceram, mantêm o hábito de seus pais, que jogavam bola no mesmo campo de areia (Figura 8). Nos bares, o som vai às alturas, torcedores fazem suas apostas, os jogadores comemoram a vitória, a derrota e a vida. Parte da areia é ocupada por barcos, barracas, sombreiros e os times de

20. Esse fragmento faz parte do processo de pesquisa do Trabalho final de Graduação de Marina Muniz acerca da relação entre as materialidades e imaterialidades da orla de Periperi, bairro do Subúrbio Ferroviário de Salvador. Para mais detalhes, ver: FERREIRA, M. M. Entre o ferro e o mar. 2019. 9of. Trabalho Final de Graduação (Bacharelado em Arquitetura e Urbanismo) - Faculdade de Arquitetura, Universidade Federal da Bahia, Salvador, 2019.

21. Entre as quais, cabe citar a intervenção da Prefeitura Municipal de Salvador na ocupação Guerreira Zeferina do Movimento do Sem Teto da Bahia em 2016, mais conhecida como Cidade de Plástico, situada na orla de Periperi. 
altinha. Os pescadores e comerciantes ambulantes utilizam dos dias de " $b a b a$ "22 para vender aos torcedores, jogadores, banhistas e funcionários dos bares.

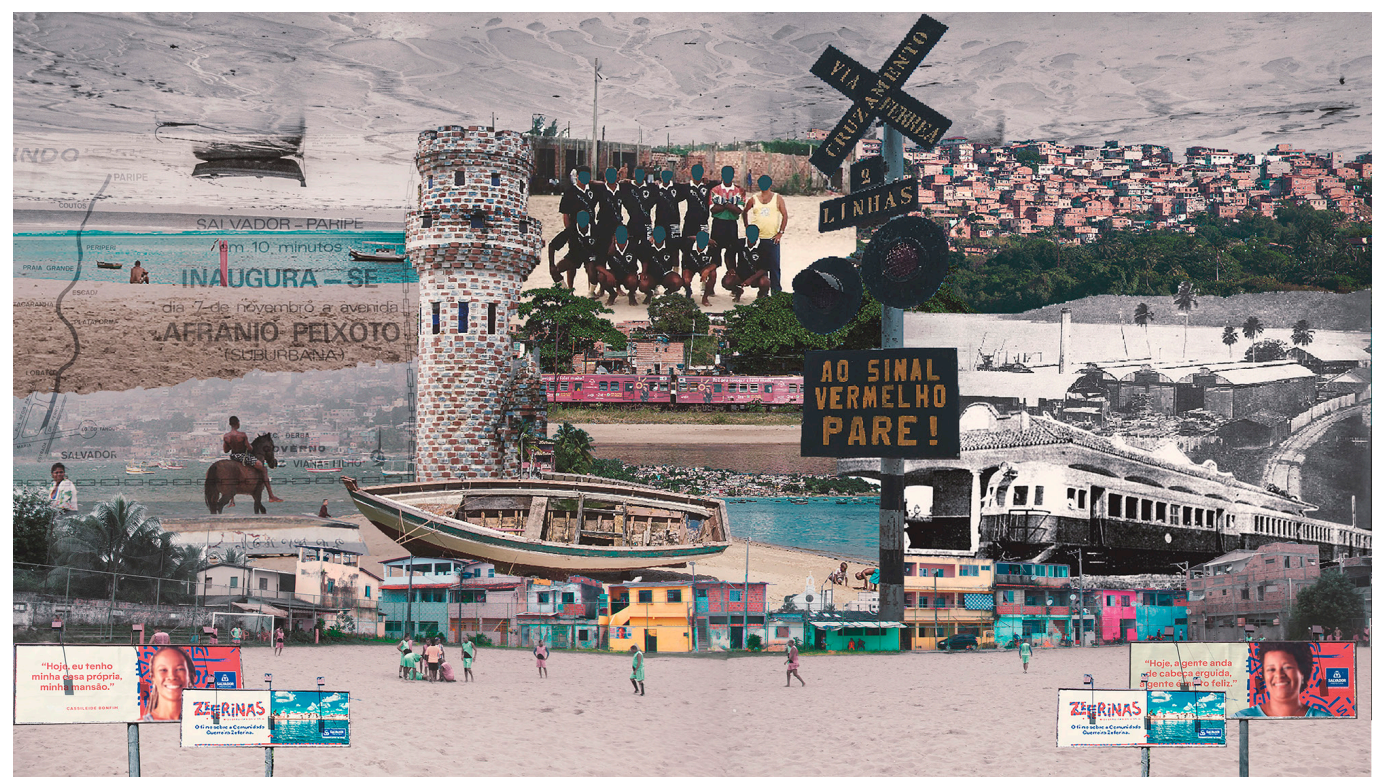

Figura 8. Fazer-cidade entre o ferro e o mar

Fonte: Acervo do grupo de estudos Margear. Autoria de Marina Muniz, 2020.

Quase como a maré, a praia muda durante a semana. Mas uma regra se mantém independentemente do dia: as pessoas presentes são, em sua maioria, homens, quase todos negros. Em 2019, quando realizamos os trabalhos de campo da pesquisa, apenas uma mulher frequentava assiduamente os bares. Apaixonada por futebol, durante a Copa do Mundo de Futebol Feminino, ela exigia que o bar a transmitisse na TV, e estes foram os únicos dias em que não a vi com a atenção voltada para o jogo da Velha Guarda.

Já Marília, moradora de uma das casas em frente ao campo de areia, não costuma frequentar os jogos, apesar de seu esposo ser considerado um dos melhores jogadores da associação. Tanto as águas salgadas quanto as doces se fazem presentes na trajetória de Marília: mariscava quando era mais jovem e ajudava a mãe, que havia sido lavadeira em uma das fontes de Periperi, seco devido à urbanização da região.

Foi Marília que nos levou à Marcela, evidenciando uma rede de sociabilidade quase familiar entre as moradoras da rua. Ela nos contou que sua mãe se mudou de São Francisco do Conde, no Recôncavo Baiano, e ocupou o terreno onde hoje

22. "Baba" é uma expressão soteropolitana para se referir ao futebol. 
mora com suas três filhas. "O terreno estava vazio, porque ninguém queria morar onde era cheio de mato, de esgoto e de ebó" ${ }^{23}$. As pessoas ficavam desconfiadas das oferendas que se acumulavam no terreno e por isso ninguém o havia ocupado antes de sua mãe.

Conforme a família foi crescendo, a casa também precisou crescer. Então, Ana, filha de Marcela, e seus tios, construíram um anexo de madeira para sua avó no terreno aos fundos. Ana enfatiza que a avó, que é do candomblé, não gosta de construção de blocos, por isso a preferência por madeira. Hoje as paredes internas e externas da casa possuem obras de arte de diversas materialidades: pinturas, grafites, mosaicos, de autoria tanto de Marcela quanto de Ana. Logo na frente da casa, existe um jardim feito com pneus reutilizados: "estavam jogando muito lixo ali, então fizemos o jardim para que parassem". Os vizinhos se apropriaram da ideia e a reproduziram em outros espaços, como no córrego que dá na praia.

A trajetória de Marcela evidencia também quanto as intervenções urbanas interferem nas vidas atreladas às águas. Ela é marisqueira, filha de marisqueira, cresceu mariscando e vendo as transformações da cidade incidindo nas águas e na vida de sua família. Ressaltou que, antes da canalização do rio Paraguari²4, ela mariscava em Periperi, na praia que considera o quintal de sua casa. Após essa intervenção, o rio passou a receber dejetos que seguem para o mar, deixando a praia imprópria para o banho e para a mariscagem. Hoje ela marisca em Plataforma, onde fica a Associação de Marisqueiras do Subúrbio Ferroviário de Salvador, e utiliza o trem ${ }^{25}$ para chegar até lá.

Da água doce à água salgada, as narrativas das moradoras de Periperi evidenciam a presença de um modo de viver em relação com os meios naturais, os quais vão muito além de recursos: eles definem a escolha pelo local de moradia, a possibilidade de trabalho e de permanência no território, atravessam as práticas de religiosidade e as gerações familiares. As águas permeiam a dimensão cotidiana e ancestral das narrativas de ambas as mulheres, que, por sua vez, atuam diretamente no cuidado com esses meios. Os meios aquosos são articulados por elas

23. Termo com diversos significados, oriundo de religiões de matriz africana, usado pela moradora em referência a uma oferenda feita geralmente em agradecimento a bênçãos recebidas ou na intenção de superar obstáculos.

24. A canalização e macrodrenagem do rio Paraguari, nos limites entre os bairros Periperi e Nova Constituinte, realizada pela gestão municipal, em 1992, foi justificada pela Prefeitura de Salvador em razão do adensamento populacional da área, onde, em épocas de chuva, as enchentes seriam recorrentes.

25. O trem do Subúrbio Ferroviário de Salvador foi desativado em fevereiro de 2021 pelo Governo do Estado da Bahia, para a implantação de um monotrilho, ameaçando diversos modos de vida das populações majoritariamente negras que dele dependiam, ficando expostas à vulnerabilidade social e a incertezas sobre seus futuros. 
através de práticas cotidianas aprendidas ao longo das gerações; modos de vida que demonstram um "processo de constituição de coletividades negras enquanto qualificadoras de um espaço” (RATTS, 2007, p. 59).

\section{Fios soltos}

A produção de conhecimento nos encontros entre mulheres, tal como propomos, pressupõe, sobretudo, que sejamos afetadas pelas trajetórias urbanas que cruzam nossos caminhos. Esse exercício tem sido essencial para pensarmos o fazer-cidade no trânsito entre escalas, dados os agenciamentos que as mulheres realizam em seus diversos trânsitos cotidianos (Figura 9). Esses encontros têm trazido para a reflexão outras noções de casa, de cidade, de relações com o território, de políticas de cuidado, e até mesmo outras dimensões da própria produção de conhecimento. Logo, os territórios populares e negros de Salvador são evocados em nossas pesquisas não apenas como paisagem ou contexto, mas também como constructo indissociável dos modos de vida.

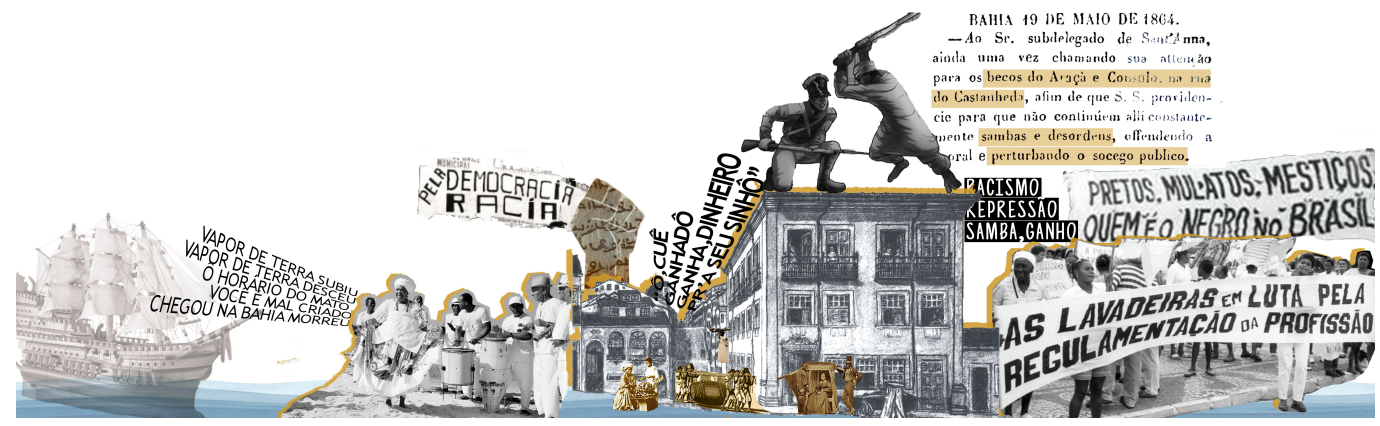

Figura 9. Diásporas, ancestralidades negras e lutas urbanas

Fonte: Acervo do grupo de estudos Margear. Autoria de Aleida Batistoti, Ingrid Pita e Yago Souza, 2019.

Os fragmentos que foram expostos, trazidos de aproximações multimetodológicas, incluem incursões aos territórios, dos quais somos, em alguns casos, moradoras e, em outros, pesquisadoras não residentes. Costuramos reflexões inter/ transdisciplinares que ensejam abarcar diferentes dimensões da vida imbricadas no fazer-cidade. Nessas experimentações metodológicas, exercitamos, também, estratégias de narração com linguagens ligadas não apenas à escrita, ensaiando formas de narrar, pesquisar e refletir que tensionam uma massiva produção acadêmica que tem privilegiado o texto e sujeitado imagens à função ilustrativa.

A reflexão sobre como produzir conhecimento nos encontros entre mulheres e seus diferentes mundos não se esgota neste artigo, pelo contrário, segue com afinco a proposta de construção contínua e compartilhada de conhecimentos. 
Muitas das referências trazidas para esse debate têm aberto caminhos para outras perspectivas no campo dos estudos urbanos, mas carecemos ainda de um arcabouço teórico que possa incidir na formação não só de pesquisadoras, como também de arquitetas e urbanistas, de modo a evitar que recaiam na reprodução de hierarquias, violências, interdições e apagamentos dos muitos processos que são estruturantes do Brasil e de Salvador.

Longe da proposição de síntese das ideias e práticas aqui mobilizadas, este texto é uma mistura de agendas de pesquisa com compartilhamento de inquietações e reflexões. Ele possui um caráter intrinsecamente transitivo e aproximativo, visto que o grupo de estudos é um espaço de formação continuada, aberta e processual; as reflexões, os compartilhamentos e os adensamentos teóricos nunca findam. Além disso, vale sublinhar que manifestamos uma intencionalidade de pesquisa política e eticamente comprometida com questões que nos são muito caras, reiterando a importância da construção coletiva das agendas de estudo, nas quais temos buscado nos inserir e participar da construção.

Cientes de que não estamos sozinhas, sequer na dianteira dessas reflexões, assumimos o desafio da articulação em rede, compreendendo as limitações de difusão e acesso à produção científica deslocada do eixo Rio/São Paulo. Reconhecemos, ainda, que ir além dos parâmetros hegemônicos para perceber a cidade é um exercício constante; algumas vezes, mesmo engajadas com o tensionamento ou com a ruptura de modos de pesquisar, pensar e narrar informados por parâmetros hegemônicos, acabamos por reproduzir as premissas de uma estrutura acadêmica colonialista, eurocentrada e pautada pela branquitude. A própria escrita coletiva mostra-se como um desafio; via de regra, na universidade, estimula-se a individualidade e a competitividade e desvaloriza-se a autoria compartilhada ${ }^{26}$, o que evidencia que essa discussão também precisa ser levantada.

Nossos encontros têm reforçado demandas de pensar a cidade com e desde as margens, em constante atenção a questões que ressurgem continuamente: como fazer pesquisa sem reproduzir hierarquias, violências, apagamentos e interdições dos muitos processos que são estruturantes do Brasil e mesmo de Salvador? Como produzir conhecimento sem desconsiderar a pluriversalidade ${ }^{27}$ epistêmica de práticas e modos de vida que constituem as cidades brasileiras e latino-americanas? Como não homogeneizar e invisibilizar histórias, trajetórias, realidades e agentes

\footnotetext{
26. A exemplo, os trabalhos finais de graduação do curso de Arquitetura e Urbanismo possuem, em sua maioria, regulamentos proibitivos a trabalhos em grupo, tal como dissertações e teses.

27. Sobre o conceito de pluriversos, ver: ESCOBAR, A. Designs for the pluriverse. Durham and London: Duke University Press, 2018; DE LA CADENA, M.; BLASER, M. A World of Many Worlds. Durham: Duke University Press, 2018.
} 
do fazer-cidade cotidiano, como as mulheres negras? Deixamos em aberto essas questões, para as quais não temos respostas definitivas. De toda maneira, elas não só não podem deixar de ser feitas, como também devem ser cada vez mais acompanhadas de novas questões, à medida que negociamos e tecemos, coletivamente, novas alianças ético-políticas na pesquisa acadêmica.

\section{Referências}

AGIER, M. Do direito à cidade ao fazer-cidade: o antropólogo, a margem e o centro. MANA, V. 21, n. 3, p. 483-498, 2015.

AKOTIRENE, C. Interseccionalidade. São Paulo: Sueli Carneiro; Pólen, 2019.

AZOULAY, A. A. Desaprendendo as origens da fotografia. ZUM - Revista de Fotografia, n. 17 out., 2019. Disponível em: https://revistazum.com.br/revista-zum-17/desaprendendo-origens-fotografia. Acesso em: 18 jun. 2021.

BOSI, E. O tempo vivo da memória: ensaios de psicologia social. Cotia: Ateliê Editorial, 2003.

CARNEIRO, A. S. A Construção do Outro como Não-Ser como fundamento do Ser. Tese (Doutorado em Filosofia da Educação) - Programa de Pós-Graduação em Educação da Universidade de São Paulo, São Paulo, 2005.

COLLINS, P. H. Aprendendo com a outsider within: a significação sociológica do pensamento feminista negro. Trad. Juliana de Castro Galvão. Revista Sociedade e Estado, Brasília, v. 31, n. 1, p. 99-127, jan./abr., 2016.

CURIEL, O. Crítica poscolonial desde las prácticas políticas del feminismo antirracista. Nómadas, Bogotá, n. 26, p. 92-101, abr., 2007.

DUARTE, L. F. D.; GOMES, E. C. Três famílias: identidades e trajetórias transgeracionais nas classes populares. 1.ed. Rio de Janeiro: Editora FGV, 2008.

FELTRAN, G. Fronteiras de tensão: política e violência nas periferias de São Paulo. São Paulo: Editora Unesp; CEM; CEBRAP, 2011.

FIGUEIREDO, G.; ESTÉVEZ, B. Perícia Popular do Centro Histórico de Salvador: vida urbana negra e máquina patrimonial. In: GLEDHILL, J.; HITA, M. G.; PERELMAN, M. (Org.). Disputas em torno do espaço urbano: processos de [re]produção/construção e apropriação da cidade. 2 ed. Salvador: EDUFBA, 2020, p. 191-220.

FIGUEIREDO, G.; ESTÉVEZ, B.; ROSA, T. T. The Black City: Modernisation and fugitivities in Salvador, Bahia, Brazil. Radical Housing Journal, v. 2, p. 55-82, dec., 2020.

GONZALEZ, L.; HASENBALG, C. Lugar de negro. Rio de Janeiro: Editora Marco Zero, 1982.

GONZALEZ, L. Por um feminismo afro-latino-americano: ensaios, intervenções e diálogos. Organização Flávia Rios e Márcia Lima. Rio de Janeiro: Zahar, 2020.

HELENE, D. Gênero e direito à cidade a partir da luta dos movimentos de moradia. Cadernos Metrópole, São Paulo, v. 21, n. 46, p. 951-974, set./dez., 2019. 
HITA, M. G. A casa das mulheres n'outro terreiro: famílias matriarcais em Salvador. Salvador: EDUFBA, 2014.

HOOKS, b. Choosing the margin as a space of radical openness. In: Yearning: race, gender and culture politics. Cambridge: South End Press, 1990, p. 223-225.

. Ensinando a transgredir: a educação como prática da liberdade. São Paulo: WMF Martins Fontes, 2017.

IHAC. Instituto de Humanidades, Artes e Ciências. IHAC:|digital: Travessias, performatividades e negritudes. Aula inaugural (Live). Salvador, 2020. Disponível em: https://www. youtube.com/watch?v=Lev6WyDpje4. Acesso em: 11 set. 2020.

ITIKAWA, L. F. Mulheres na periferia do urbanismo: informalidade subordinada, autonomia desarticulada e resistência em Mumbai, São Paulo e Durban. Revista Brasileira de Estudos Urbanos e Regionais, v. 18, n. 1, p. 57-76, jan./abr., 2016.

MACEDO, R. S.; MACEDO DE SÁ, S. M. A etnografia crítica como aprendizagem e criação de saberes e a etnopesquisa implicada: entretecimentos. Currículo sem Fronteiras, online, v. 18, n. 1, p. 324-336, jan./abr., 2018.

MARTINS, L. M. Performances da Oralitura: corpo, lugar da memória. Revista do programa de pós-graduação em letras, Universidade Federal de Santa Maria, Santa Maria, n. 26, p. 63-81, jun., 2003.

MBEMBE, A. Poder brutal, resistência visceral. Série Pandemia. São Paulo: N-1 Edições, 2019.

MCKITTRICK, K. On plantations, prisons, and a black sense of place. Social \& Cultural Geography, v. 12, n. 8, p. 947-963, 2011.

URIARTE, U. M. Como narrar o campo: reflexões provocadas pela oficina "Insistências urbanas”. Redobra, Salvador, n. 12, p. 130-135, 2013.

MORTIMER, J. Arquiteturas do olhar: imaginários fotográficos do espaço construído. Belo Horizonte: C/Arte, 2017.

Pensar por imagens. In: JACQUES, P. B.; PEREIRA, M. (Org.). Nebulosas do pensamento urbanístico. Tomo I - modos de pensar. Salvador: Edufba, 2018, p. 148-175.

MOTTA, E. Casas e economia cotidiana. In: RODRIGUES, R. I. (Org.). Vida social e política nas favelas: pesquisas de campo no Complexo do Alemão. Rio de Janeiro: Ipea, 2016, p. 197-214.

MOURA, C. Escravismo, colonialismo, imperialismo e racismo. Afro-Ásia, v. 14, p. 124-137, 1983.

OBSERVATÓRIO DAS METRÓPOLES. Panorama das condições de trabalho de homens e mulheres no centro do Rio de Janeiro. Rio de Janeiro: Observatório das Metrópoles; Movimento Unido dos Camelôs, 2019.

PAOLI, M. C. Memória, história e cidadania: o direito ao passado. In: DEPARTAMENTO DO PATRIMÔNIO HISTÓRICO. $O$ direito à memória: patrimônio histórico e cidadania. São Paulo: DPH, 1992, p. 25-28.

PEIRANO, M. Etnografia não é método. Horizontes Antropológicos, Porto Alegre, ano 20, n. 42, p. 377-391, jul./dez., 2014. 
PEREIRA, G. L. Apontamentos sobre a dimensão imaginativa da existência negra nas cidades. In: SALVADOR E SUAS CORES, 4, 2018, Salvador. Anais do IV Salvador e suas cores. Salvador: UFBA, 2018.

. Direito à cidade e questões raciais. Coletiva, [s. 1.], jun. 2019. Disponível em: https:// www.coletiva.org/direito-a-cidade-e-questoes-raciais. Acesso em: 26 nov. 2019.

PINHO, I. V. Casa de mulher: os circuitos cotidianos de cuidado, dinheiro e violência em São Carlos/SP. Dissertação (Mestrado em Sociologia) - Programa de Pós-Graduação em Sociologia, Universidade Federal de São Carlos, São Carlos, 2019.

RAMOS, M. E. R. Bairros Negros: uma lacuna nos estudos urbanísticos - um estudo empírico-conceitual no bairro do Engenho Velho da Federação, Salvador (Bahia). Tese (Doutorado em Arquitetura e Urbanismo) - Programa de Pós-graduação em Arquitetura e Urbanismo, Universidade Federal da Bahia, Salvador, 2013.

RATTS, A. O mundo é grande e a nação também: identidade e mobilidade em territórios negros. Tese (Doutorado em Antropologia Social) - Programa de Pós-Graduação em Antropologia Social, Universidade de São Paulo, São Paulo, 2001.

.Eu sou Atlântica: sobre a trajetória de vida de Beatriz Nascimento. 1. ed. São Paulo: Imprensa Oficial; Instituto Kuanza, 2007.

. Os lugares da gente negra: temas geográficos no pensamento de Beatriz Nascimento e Lélia Gonzalez. In: SANTOS, R. E. (Org.). Questões urbanas e racismo. Petrópolis: DP \& A; ABPN, 2012, p. 216-243.

RIBEIRO, A. C. T. Dança de sentidos: na busca de alguns gestos. In: BRITTO, F. D.; JACQUES, P. B. (Org.). Corpocidade: debates, ações e articulações. Salvador: EDUFBA, 2010, p. 24-41.

. Homens lentos, opacidades e rugosidades. Redobra, Salvador, n. 9, p. 58-71, 2012.

ROSA, T. T. Favelas, periferias: uma reflexão sobre conceitos e dicotomias. In: XXXIII ENCONTRO ANUAL DA ANPOCS, Caxambu, 2009. Anais eletrônicos [...]. São Paulo: ANPOCS, 2009. Disponível em: https://anpocs.com/index.php/encontros/papers/33-encontro-anual-da-anpocs/gt-28/gto1-20. Acesso em: 14 jan. 2021.

Cidades outras: pobreza, moradia e mediações em trajetórias urbanas liminares. Tese (Doutorado em Arquitetura e Urbanismo) - Instituto de Arquitetura e Urbanismo de São Carlos, Universidade de São Paulo, São Carlos, 2014.

Pensar por margens. In: JACQUES, P. B.; PEREIRA, M. (Org.). Nebulosas do pensamento urbanístico. Tomo I - modos de pensar. Salvador: Edufba, 2018, p. 176-204.

SIMONE, A. People as infrastructure: intersecting fragments in Johannesburg. Public Culture, online, n. 16, v. 3, p. 407-429, 2004.

SODRÉ, M. O terreiro e a cidade: a forma social negro-brasileira. Rio de Janeiro: Imago Editora; Salvador: Fundação Cultural do Estado da Bahia, 2002.

TVARDOVSKAS, L. S.; NAVARRO-SWAIN, T. O imaginário habitado: gênero, história e cultura visual. In: SCHIAVINATTO, I.; MENESES, P. (Org.). A imagem como experimento: debates contemporâneos sobre o olhar. Vitória: Editora Milfontes, 2020, p.113-124.

WEIL, S. O enraizamento. In: BOSI, E. (org.). A condição operária e outros estudos sobre a opressão. 2. ed. Rio de Janeiro: Paz e Terra, 1996, p. 411-412. 


\section{Vanessa Alves Cordeiro}

Urbanista e arquiteta (UFPI), especialista em Planejamento Urbano e Gestão Socioambiental das Cidades (UFPI), mestranda em Arquitetura e Urbanismo (PPGAU/ UFBA), integrante do grupo de estudos Margear (UFBA).

Email: cordeiro.vanessa@ufba.br

ORCID: 0000-0002-9551-0219

Contribuição de autoria: Conceituação, Curadoria de Dados, Investigação/Pesquisa, Administração do Projeto, Escrita - Primeira Redação, Escrita - Revisão e Edição.

\section{Aleida Fontoura Batistoti}

Urbanista e arquiteta (UCDB), especialista em Assistência Técnica, Habitação e Direito à Cidade (RAU+E/UFBA), mestranda em Arquitetura e Urbanismo (PPGAU/UFBA), integrante do grupo de estudos Margear (UFBA).

Email: aleidabatistoti@gmail.com

ORCID: $0000-0002-5952-8438$

Contribuição de autoria: Conceituação, Curadoria de Dados, Investigação/Pesquisa, Administração do Projeto, Escrita - Primeira Redação, Escrita - Revisão e Edição.

\section{Zara Pereira Rodrigues}

Urbanista e arquiteta (UFBA), integrante do grupo de estudos Margear (UFBA).

Email: zara.prs14@gmail.com

ORCID: 0000-0001-7649-9918

Contribuição de autoria: Conceituação, Curadoria de Dados, Investigação/Pesquisa, Escrita - Primeira Redação, Escrita - Revisão e Edição. 


\section{Marina Silveira Muniz Ferreira}

Urbanista e arquiteta (UFBA), mestranda em Arquitetura e Urbanismo (PPGAU/UFBA), integrante do grupo de estudos Margear (UFBA) e do Coletivo Trama de multilinguagens.

Email: marinamuinz.arq@gmail.com

ORCID: 0000-0002-3013-2691

Contribuição de autoria: Conceituação, Curadoria de Dados, Investigação/Pesquisa, Escrita - Primeira Redação, Escrita - Revisão e Edição.

\section{Atailon da Silva Matos Silva}

Engenheiro Civil (UNIFACS), mestrando em Arquitetura e Urbanismo (PPGAU/UFBA), integrante do grupo de estudos Margear (UFBA), do grupo de Pesquisa Lugar Comum e do Coletivo Trama de multilinguagens.

Email: atailonmatos@gmail.com

ORCID: 0000-0002-8277-221X

Contribuição de autoria: Conceituação, Curadoria de Dados, Investigação/Pesquisa, Escrita - Primeira Redação, Escrita - Revisão e Edição.

Submissão: 21 de dezembro de 2020.

Aprovação: 20 de julho de 2021.

Como citar: ALVES CORDEIRO, V.; BATISTOTI, A. F.; RODRIGUES, Z. P.; FERREIRA, M. S. M.; SILVA, A. da S. M. Como produzir conhecimento nos encontros entre mulheres? Reflexões sobre experiências teórico-metodológicas com e desde as margens da cidade. Revista brasileira de estudos urbanos e regionais. Dossiê Território, Gênero e Interseccionalidades. v. 23, E202130, 2021. DOI 10.22296/2317-1529.rbeur.202130

Artigo licenciado sob Licença Creative Commons CC BY 4.0.

https://creativecommons.org/licenses/by/4.o/deed.pt_BR 